\title{
Discussion on the Classification of the Apartments for the Aged
}

\author{
Bianling Zhang \\ Huanghe Science and Technology College \\ Zhengzhou, China
}

\begin{abstract}
With discussion about the types of the apartments for the elderly based on two major variables, the paper indicates that the apartments for the elderly are an important part of social facilities for the aged. As the standards for their classification are diversified, the elderly should seek for occupancy according to their individual circumstances.
\end{abstract} based

Keywords-apartments for the elderly; service-based; care-

\section{INTRODUCTION}

Becoming an ageing country in 1999, China is one of the countries having the largest population and the fastest growth of the aged. It has been shown that by the mid-twentieth century the aged population over 60 in China will reach about 440 million, taking up $36 \%$ and $22.3 \%$ of the aged population in Asia and in the world, respectively. The scale of the aged population and the speed of ageing in China are unprecedented in the world's population development history. In the foreseeable future the residential buildings suitable for the physical and mental states of the aged will be inevitably a concern in the architectural design circle.

The apartments for the elderly prevailing in developed countries are a special housing mainly designed for healthy old people based on their physiological and psychological features, with bedrooms, living rooms, bathrooms, kitchens, etc. included. Providing various service, cultural, recreational and medical facilities and having professional service personnel to serve the elderly occupants, the apartments are an extension of community service. Combining home-based care and community service, they not only remain faithful to the tradition of China's family supporting, but also gear to the international social supporting mode. While enabling the aged to have an independent dwelling unit and maintain a homely atmosphere, they also ensure them a better service and care, winning popularity among the aged. Due to the great differences of the aged in economic level, life style, life ideas and health conditions, their demand for services is inevitably diversified, resulting in diversified types of the apartments for the aged. As the standards for classification of the apartments for the aged are various, the paper now classify the types of the apartments for the aged based on the two major variables as follows: the degree of the independent ability of the aged and the housing relationship between the aged occupants and the average occupants.

\section{ClASSIFICATION ACCORDING TO THE DEGREE OF THE INDEPENDENT ABILITY OF THE AGED}

The degree of the independent ability of the aged determines the privacy degree of their dwelling environment and the mode and level of providing service for them. Generally, with the impairment of independent ability, the privacy degree of the dwelling environment of the aged will be relatively reduced, and the mode and level of providing service for them should be boosted accordingly. The period from the aged entering their old age to their death approximately includes four phases: the independent; the partially assisted; the fully assisted and the end.

It is a general trend of senility among the aged from the independent phase to the end. According to the differences of the degree of needing social assistance at every phase of the aging process of people, the International Charities (HTA) established, for classification of the residential buildings for the aged in 1986, a standard, which classifies these buildings into seven types "Table 1" to suit the development trend of the mechanisms of ageing of human beings. Referring to the standard above and combining the differences of the independent ability of the aged, the paper tries to classify the apartments for the aged into three types: the independent apartment, the service-oriented apartment and the careoriented apartment.

\section{A. The Independent Apartment for the Aged}

This type of apartments for the aged is basically similar to the average apartments, designed to be fully accessible for the people with disabilities. The occupants are heathy aged people who are rigorous, basically capable of living independently and in want of somewhat care and little help.

\section{B. The Service-oriented Apartment for the Aged}

This type of apartments for the aged has special service personnel to provide the aged with services necessary for everyday life, including food, laundering, etc. The occupants are the aged who are health and vigorous. 
TABLE 1 INTERNATIONAL CHARITIES (HTA) CLASSIFICATION OF RESIDENTIAL BUILDINGS FOR THE AGED

\begin{tabular}{|c|c|}
\hline $\begin{array}{c}\text { HTA } \\
\text { Classification }\end{array}$ & Degree of Providing Service for Occupants \\
\hline 1 & $\begin{array}{l}\text { Houses for the non-aged or for the vigorous aged before } \\
\text { and after retirement, who have self-care independence to } \\
\text { live in their own apartments. }\end{array}$ \\
\hline 2 & $\begin{array}{l}\text { Houses for the healthy aged people who are vigorous, } \\
\text { have basic ability of self-care independence and need } \\
\text { somewhat care and little help, including the original } \\
\text { houses specially reconstructed. }\end{array}$ \\
\hline 3 & $\begin{array}{l}\text { Houses specially built for healthy and rigorous aged } \\
\text { people, with facilities helping them live a basically } \\
\text { independent life, providing round-the-clock care, } \\
\text { minimum levels of service and utilities. }\end{array}$ \\
\hline 4 & $\begin{array}{l}\text { Houses specially for the aged who are physically weak } \\
\text { and mentally sound. The occupants need no medical care, } \\
\text { but occasionally require help and care for personal life, so } \\
\text { these house need provide round-the-clock care and food } \\
\text { provision when required. }\end{array}$ \\
\hline 5 & $\begin{array}{l}\text { Houses for the aged who are physically sound and } \\
\text { mentally weak. The occupants may need some personal } \\
\text { life care. The utilities can be the same as category } 4 \text {, but } \\
\text { nursing personnel can be provided as required. }\end{array}$ \\
\hline 6 & $\begin{array}{l}\text { Old-age homes for the aged who both physically and } \\
\text { mentally weak and need personal care. The occupants are } \\
\text { mostly unable to take care of themselves, so that the } \\
\text { houses are not detached and can provide services like } \\
\text { food, bath, cleaning and dressing, etc. }\end{array}$ \\
\hline 7 & $\begin{array}{l}\text { Nursing homes, whose occupants, in addition to that as } \\
\text { mentioned in } 6 \text {, include temporary and permanent } \\
\text { patients suffering from an illness and injury. These } \\
\text { buildings should have registered medical institutions, } \\
\text { with one-bed rooms provided. }\end{array}$ \\
\hline
\end{tabular}

\section{The Care-oriented Apartment of the Aged}

This type of apartments for the aged is specially designed for the device-aided elderly who are physically weak and mentally sound. Apart from the services provided by a service-oriented apartment, the apartments provide roundthe-clock care and comprehensive help and attendance except medical care. The occupants of the independent and service-oriented apartments are basically the same-the aged who can take care of themselves. However, these two types of apartments have great differences in the mode and degree of providing services for the aged. The service-oriented type, providing more comprehensive and in-depth service, imposes a higher charge than the average apartments do, so that the aged can make a choice for occupancy according to their own situation. The apartments for the aged in China now are mostly that combining the service-oriented and the care-oriented, providing corresponding services and care for the aged according to their health. The advantaged of these apartments are that the aged can long live in their familiar environments, have relatively regular groups of interaction and gain systematic services and care. The independent apartments for the aged, however, are few in China. Basically similar to the average apartments, this independent type is just designed to be fully accessible for the people with disabilities. As the occupants are the aged who are heathy and rigorous, the service personnel only need to provide some help and necessary care for them. Compared with the service-oriented and care-oriented types, the independent type has the advantage of strong privacy.
Therefore, it is very suitable for the aged who are healthy and independent and have a higher request for privacy.

\section{CLASSIFICATION ACCORDING TO THE INTERRELATION BETWEEN THE AGED OCCUPANTS AND THE AVERAGE OCCUPANTS}

According to the relationship between the aged occupants and the average occupants, the paper tries to classify the apartments for the aged into two types: the specializedresidential apartment and the mixed-residential apartment.

\section{A. Specialized-residential Apartments: Those Whose Occupants Are All Aged People}

They can be located at a corner of a residential quarter or outside of it where there is beautiful scenery. The shortcomings of this type of apartments are that the aged cannot conveniently interact with other occupants in different age groups in the same quarter and they will have bad mental attitude like loss, loneliness, etc. However, the advantages of this type of apartments are obvious. They are not only favorable to reach a certain scale for unified management and good economic benefit, but also easy for the aged to interact with each other. Besides, with the barrier-free design getting increasingly popular, the problem of the interaction between the aged and other occupants in different age groups will be significantly improved. Especially the specialized-residential apartments built on the sites boasting beautiful scenery, they can better meet the demand of the aged for getting close to nature and for recreation and entertainment. Judging from the examples of the apartments for the aged at both home and abroad, this type of apartments accounts for the majority and presently constitutes the principal type of the apartments for the aged in China.

\section{B. Mixed-residential Apartments: As the Name Suggests, They Are the Apartments in Which the Aged Occupants Live Together with the Average Occupants}

This type of apartments is in favor of the close interaction between the aged occupants and the other occupants in different age groups. However, in a mixed-residential apartment, the aged occupants take up a small percentage, so that it is inconvenient for centralized management and impossible to form scale benefits. Meanwhile, the differences, quite a few, in the design requirements between the apartments for the aged and the average ones will cause so much inconvenience to design and construction. The mixed-residential apartments, well solving the problems of interaction between the aged and other occupants in different age groups and being in favor of the aged to take a positive and upbeat attitude, are a type of great potential. Based on none other than the advantages above, this type of apartments for the aged is emerging in some fairly economically developed cities in South China. For example, the largest "Wonderful" chain apartment for the aged in Nanjing, which is integrated in the average apartment buildings in the neighborhoods like Luyin Garden, Dongfeng City, is convenient for the aged to communicate with society 
and their relatives and friends, so that it is very successful and popular.

\section{REFERENCES}

[1] Zhai Jingfeng. Research on Planning and Design of Social Facilities for the Aged in Urban Communities-(1) Design Research of Project Planning and Overall Architectural Plan [D]. A magisterial thesis of the Southeast University.

[2] Zou Guangtian. Planning and Design of Japan Apartments for the Aged [J]. World Architecture, 1999, (4): 31-33. 